\title{
RAPD ANALYSIS TO DETECT SOMACLONAL VARIATION OF PINEAPPLE In Vitro CULTURES DURING MICROPROPAGATION
}

\author{
IKA ROOSTIKA ${ }^{1 *}$, NURUL KHUMAIDA ${ }^{2}$ and SINTHO WAHYUNING ARDIE ${ }^{2}$ \\ ${ }^{1}$ Indonesian Center for Agiailtural Bidtechndogyand Gentic Resares RearchandDevdqumet (ICABIOGRAD) \\ Bogr 16111, Indanesia \\ ²Department of Agronomyand Hotialture, Institut Petarian Bogr, \\ Bogr 16680, Indonesia
}

Received 7 September 2014/ Accepted 20 Januari 2015

\begin{abstract}
ABST RACT
Plant off-type becomes a concern in pineapple micropropagation. Reliable methods are needed to detect and to reduce plant off-type. This research was conducted to confirm the occurrence of somaclonal variation during micropropagation of pineapple clone Simadu. The culture period (long- and short-period) and the regeneration methods (direct organogenesis, indirect organogenesis and somatic embryogenesis) were studied to know their contribution in bringing out somaclonal variation. RAPD analysis using 10 primers was performed to confirm genetic variation. The result showed that RAPD assay could be applied as early detection of somaclonal variation of pineapple, where OPA primers were better to be used than OPJ primers. The phenotypic variation occurred in the four year-old pineapple plants and plantlets were due to genetic variation. It has proved that the long-period of cultures is the main contributor of somaclonal variation, while the regeneration method and plant growth regulator could also induce genetic variation. The new cultures showed higher level of similarity. Therefore, it needs a correct strategy to apply micropropagation method of pineapple to minimize plant off-type. It was recommended to avoid the use of long-period culture as mother stock and to apply direct organogenesis method for micropropagation rather than indirect organogenesis and somatic embryogenesis.
\end{abstract}

Keywonds: Anamascomous(L.) Merr,, molecularmarkers, plant off-type

\section{INTRODUCTION}

Conventionally, pineapple can be propagated from various plant propagules, namely crown, sucker, butt or stump, hapas, ratoons and slip. However, their reproductive time is not uniform (International Board for Plant G enetic Resources 1991; Coppens d'Eeckenbrugge \& Leal 2003). Conventional propagation techniques were not appropriate for rapid mass propagation, such as in cultivar Smooth Cayenne, where availability of vegetative propagules are commonly limited both in the type (only crown and sucker) and the number. Invitroculture techniques may be able to solve the problem, since it can provide alternative methods for mass propagation plants with higher uniformity and at shorter times. According to

\footnotetext{
*Corresponding author : ikatambunan@ yahoo.com
}

Smith $\&$ al. (2003), micropropagation has been used for establishment of multiplication blocks, which then provide conventional planting material for larger production blocks, because the micropropagated plants are more expensive and the growers concern about the genetic off-type.

It was reported that variation may be resulted from the pre-existing variation of the explants (Wakasa \&al. 1979; Nwauzoma \& Jaja 2013), the long period of the culture (Koornneef 1991; Masoud \& Hamta 2008), the high level of plant growth regulator (Bairu $\notin$ al. 2006), the frequent subculture (Eeuwens $\&$ al. 2002), the genotype dependence (Zucchi $\notin$ al. 2002), activation of transposable elements (Bairu $\notin$ al. 2011), and hypo- or hypermethylation of D NA (Abdellatif $\notin$ al. 2012). To avoid the high level of variation and to streamline the efficiency of micropropagation method, it needs a strategy to produce uniform 
genetic identity in the seedlings. Therefore, variations in the mother stocks and regenerants need to be characterized. Based on the morphological characterization of invitrocultures and phenotypic evaluation of the seedlings in the previous research, it was suggested that those variations were caused by somaclonal variation (Roostika 2012a). In order to confirm this suggestion, molecular analysis needs to be conducted.

Molecular markers are widely used to detect somaclonal variation and genetic fidelity during micropropagation (Tawar \& al. 2008; Rout $\&$ al. 2009; Khoddamzadeh \& al. 2010; Shahid \& al. 2014). Randomly A mplified Polymorphism D NA (RAPD) is applied because it is useful for analysis of variation at many loci requiring small quantities of DNA, but not prior knowledge of DNA sequence nor involvement of radioactivity (Williams $\&$ al. 1990). In the case of pineapple, RAPD analysis has been performed to detect genetic fidelity and variants of A. comosus var Queen (Soneji \& al. 2002), A. comosus var Amarelinho (Feuser $\notin$ al. 2003), A. comosus var bracteatus (Santos $\&$ al. 2008) and the promising clone Golden Pineapple (Suminar 2010). The objectives of this study were: (1) to confirm the occurrence of somaclonal variation by RAPD method; (2) to know the level of variation of regenerants derived from four regeneration methods (axillaries shoot proliferation, direct organogenesis, indirect organogenesis, and somatic embryogenesis); and (3) to detect the variation and to reduce thelevel of variation.

\section{MATERIALS AND METHODS}

\section{Plant Materials}

The plant materials were four-year-old pineapple cultures of Simadu (Smooth Cayenne) from Subang, West Java, Indonesia. There were three populations used in this research.

\section{Preparation of Population I}

The cultures were established from axillary bud explants, excised from the crown of pineapple plants grown in the field. The explants were sterilized using $70 \%$ ethanol and $10.5 \%$ sodium hypochlorite. The basal medium was MS salt (Murashige \& Skoog 1962), 3\% (w/v) sucrose,
0.8\% (w/ v) agar, $100 \mathrm{mg} / \mathrm{L}$ myo-inositol, 0.1 $\mathrm{mg} / \mathrm{L}$ thiamine $\mathrm{HCl}, 0.5 \mathrm{mg} / \mathrm{L}$ pyridoxine- $\mathrm{HCl}$, $0.5 \mathrm{mg} / \mathrm{L}$ nicotinic acid with addition of $8.84 \mu \mathrm{M}$ Benzyl Adenine (BA) and $9.3 \mu \mathrm{M}$ kinetin (Kin). Prior to autoclaving the medium, its $\mathrm{pH}$ was adjusted to $5.7 \pm 0.1$. The cultures were illuminated 16 hours per day with $20 \mu \mathrm{mol}$ photons $/ \mathrm{m}^{2} / \mathrm{s}$ irradiance provided by fluorescence lights in a culture room at $25 \pm 2{ }^{\circ} \mathrm{C}$. After a four-year invitroperiod and more than 10 times subculture, the cultures were maintained on MS basal medium with addition of $2.21 \mu \mathrm{M}$ BA and $4.65 \mu \mathrm{M} \mathrm{Kin}$. The root induction was conducted by planting the shoots onto the MS medium containing of $15 \mu \mathrm{M}$ Indole Butyric Acid (IBA) and $5.37 \mu \mathrm{M}$ Naphthalene Acetic Acid (NAA) for 3 weeks.

\section{Preparation of Population II}

The cultures that grew normally were selected. Six hundred and fifty leaf bases were isolated as sources of explants that comprised approximately $1 \mathrm{~cm}$ of basal portion of the leaves. The explants were regenerated through direct organogenesis (Roostika \&al. 2012a) and indirect organogenesis regeneration (Roostika $\&$ al. 2012b). The other cultures were prepared through indirect somatic embryogenesis as described by Roostika \& al. (2012c). The root induction medium was the same as mentioned above.

\section{Preparation of Population III}

Population III consisted of plants collected from field (Clone Simadu and Non Simadu), the new cultures of both clones derived from shoot proliferation and direct organogenesis regeneration. The axillary buds of crown were sterilized and the in vitroshoots were initiated on MS media supplemented with $8.84 \mu \mathrm{M}$ BA and $9.3 \mu \mathrm{M}$ Kin for shoot proliferation. After 6 months of culture period without subculture, they were maintained on MS media with addition of $2.21 \mu \mathrm{M}$ BA and $4.65 \mu \mathrm{M}$ Kin prior to RAPD analysis.

\section{RAPD Assay to Detect Somaclonal Variation}

The leaves of acclimated variants were used as the samples in population I. About 10 shoots of cultures were pooled to make bulk samples in population II and III. RAPD assay was performed 
Table 1 The list of primers and their sequences used in the RAPD assay

\begin{tabular}{ccc}
\hline No & Primer & Sequence $3^{\prime}$ to $5^{\prime}$ \\
\hline 1 & OPA2 & TGCCGAGCTG \\
2 & OPA3 & AGTCAGCCAC \\
3 & OPA7 & GAAACGGGTG \\
4 & OPA9 & GGGTAACGCC \\
5 & OPA13 & CAGCACCCAC \\
6 & OPA16 & AGCCAGCGAA \\
7 & OPA18 & AGGTGACCGT \\
8 & OPA19 & CAAACG TCGG \\
9 & OPJ11 & ACTCCTGCGA \\
10 & OPJ13 & CCACACTACC \\
\hline
\end{tabular}

using a modification method of Soneji \&al. (2002). The DNA samples were isolated using Cetyl Trimethyl Ammonium Bromide (CTAB). Subsequently, they were amplified by Polymerase Chain Reaction (PCR) machine. Each reaction mixture contained $1 \mu \mathrm{L} 25 \mathrm{ng} / \mathrm{L}$ genomic D NA, 1 $\mu \mathrm{L}$ primer as listed at Table 1 (Operon Tech. Alameda, USA) at $10 \mathrm{ng} / \mu \mathrm{L}, 11 \mu \mathrm{L} \mathrm{ddH}_{2} \mathrm{O}$ and 12 $\mu \mathrm{L}$ PCR mix, in a $25 \mu \mathrm{L}$ total reaction. The PCR consisted of pre-denaturation at $94{ }^{\circ} \mathrm{C}$ for 4 minutes, 40 cycles at $94{ }^{\circ} \mathrm{C}$ for 30 seconds (denaturation), $36{ }^{\circ} \mathrm{C}$ for 1 minute (annealing) and 1 minute at $72{ }^{\circ} \mathrm{C}$ (extension), post-extension at $72{ }^{\circ} \mathrm{C}$ for 5 minutes and a final extension at $40{ }^{\circ} \mathrm{C}$ for 4 minutes. The PCR products were resolved on $1.2 \%$ agarose (Promega) and electrophoresed at a constant voltage of $50 \mathrm{~V}$ for 50 minutes and then the bands were stained with Ethidium Bromide (EtBr) and visualized under a UV transiluminator. A $1 \mathrm{~kb}$ DNA ladder was used as a molecular standard. The samples were scored based on presence (coded as 1) or absence (coded as 0) of the same size bands. To select the primers, the mother plant D NA and one variant (needle leaf) were used. The primers that showed polymorphic bands and/ or scorable bands were selected. The scored data (binary data) were analyzed using the SIMQUAL, SAHN and TREE programs from the Numerical Taxonomy and Multivariate Analysis System version 2.02 (NTSY S-pc 2.02). The similarity degrees were calculated according to the Dice coefficient. Groupings were carried out using the Unweighted Pair Group Method and Arithmetic Average (UPGMA) cluster analysis.

\section{RESULTS AND DISCUSSION}

\section{Genetic Variations 0ccurred in the Long- Period In Vitro Cultures of Pineapple}

In order to determine the source of phenotypic variations occurred in the micropropagated cultures and plants, molecular analysis using RAPD markers was conducted. Plants with normal phenotype and exhibited several phenotypic variations (dwarf posture, albino stripe leaf, narrow leaf, spines spot leaf, erect posture, wider leaf, powdery leaf, climb posture, needleleaf and ultra dwarf posture) were subjected to RAPD analysis using 10 primers. OPA and OPJ have been used to characterize the variation in orchid Phalaengpsis (Chen \& al. 1998), A. comosusvar. Q ueen (Soneji \&al. 2002) and var. bracteatus (Santos \& al. 2008). The result showed that the primers of OPA were better than OPJ in generating amplified bands. The two primers generated the highest number of amplified bands, namely O PA13 and OPA 16, whereas the primer of OPJ11 produced the lowest number of amplified bands. The result showed that the phenotypic variation occurred in the population I (the four-year-old pineapple cultures were due to genetic variation as the RAPD method revealed a high polymorphism of DNA bands (Fig. 1). A total of 73 bands were amplified, 70 (95.9\%) of which were polymorphic (Table 2), indicated the high level of variation. The NTSYS analysis yielded a dendrogram where the similarity coefficient ranged from 0.32 to 0.91 with high Rohlf matrix correlation value $(r=0.97$, very 
Table2 The number of amplified product and polymorphic bands in population I, conducted by PCR method using 10 RAPD primers

\begin{tabular}{cccc}
\hline No & Primer & Number of amplified bands & Number of polymorphic bands \\
\hline 1 & OPA2 & 8 & 8 \\
2 & OPA3 & 7 & 6 \\
3 & OPA7 & 8 & 8 \\
4 & OPA9 & 7 & 6 \\
5 & OPA13 & 10 & 10 \\
6 & OPA16 & 13 & 13 \\
7 & OPA18 & 8 & 8 \\
8 & OPA19 & 6 & 6 \\
9 & OPJ11 & 2 & 1 \\
10 & OPJ13 & 4 & 4 \\
\hline & 73 & 70 \\
\multicolumn{7}{c}{ Total number of bands } & 100 & 95.9 \\
\hline
\end{tabular}

Note: Population I was derived from the four-year invitrocultures regenerated through shoot proliferation method

suitable). It separated the variants at the similarity coefficient of $0.32-0.61$ to the control plant (Fig. 2). There were $82.3 \%$ plants with altered phenotype in the Population I (Roostika $\&$ al. 2012a) and all of those variants were genetically different from the control plants (plants with normal phenotype) based on RAPD analysis. This present study clearly showed that the use of long-period cultures open a high risk of somaclonal variation for pineapple micropropagation.

\section{Regeneration Method Affects the Somaclonal Variation of Pineapple}

Based on Table 3, it seems that the OPA primers generated higher number of amplified bands than those produced by OPJ primers. The highest amplified bands were yielded from OPA2 and OPA3, whereas OPJ primers generated the lowest amplified bands. There was also a high polymorphism obtained from Population II (Fig. 3; Table 3). From a total 65 amplified products, 60 bands (92.3\%) of which were polymorphic (Table 3). The NTSYS analysis yielded a dendrogram where similarity coefficient ranged from 0.34-0.99 $(\mathrm{r}=0.98)$. It separated the variants at the similarity coefficient of 0.34-0.65 to the control plant (Fig. 4). The percentage of polymorphism was only slightly lower than Population I. This result showed that the regeneration of normal phenotype-selected cultures could only reduce a small variation. It seems that chimera might have been existed in those explants sources (Population I). Figure 4 also showed that picloram-derived cultures had the lowest similarity (0.34). Picloram is an auxinic herbicide belong to the pyridine group and commonly used at low concentration as an inducer for callus formation during somatic embryogenesis regeneration (Firoozabady \& Moy 2004; Ahmed etal. 2011; Noormi ఓal. 2012). Beside regenerated through callus formation phase, it needs a longer time to conduct somatic embryogenesis, so that the probability of genetic changes would increase. Callus is an undifferentiated structure and actively doing cell division. According to Miguel and Marum (2011), tissue culture systems that involve acquisition of competence for extensive cell division are usually regarded as more risky of genome instability. Rani and Raina (2000) reported that there was a genetic instability of seedlings derived from micropropagation via callus formation. A high polymorphism (35/ 84 bands) was also reported by Soniya etal. (2001) on tomato, cultured by picloram containing media. Several previous studies reported the contribution of plant growth regulator in somaclonal variation, but they put less consideration in period of cultures (Feuser $\notin$ al. 2003; Santos \& al. 2008). O ur study showed that the long-period of cultures is the main contributor of somaclonal variation, the regeneration method and plant growth regulator could also induce genetic variation in the in vitro culture of pineapple. 

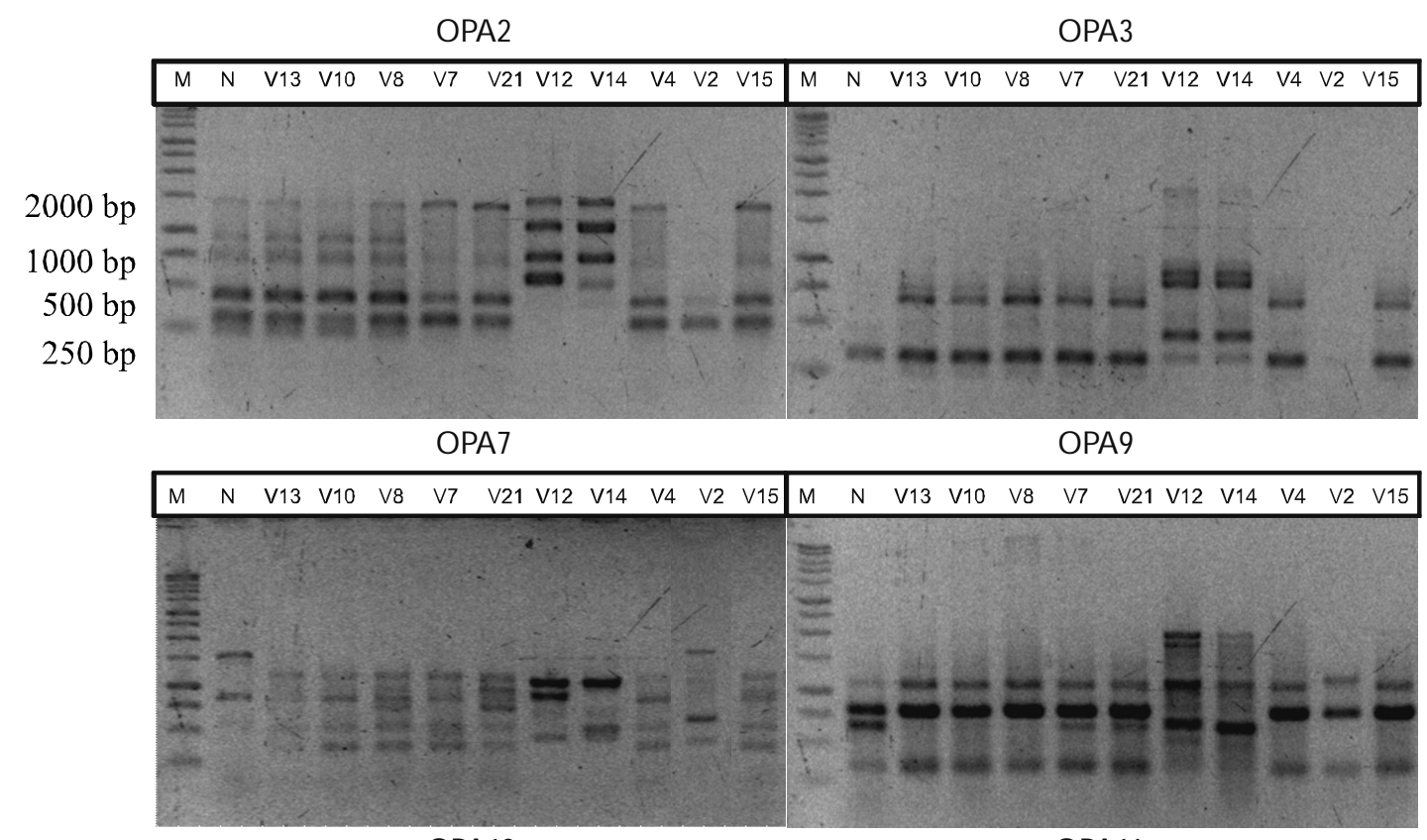

OPA13

OPA16

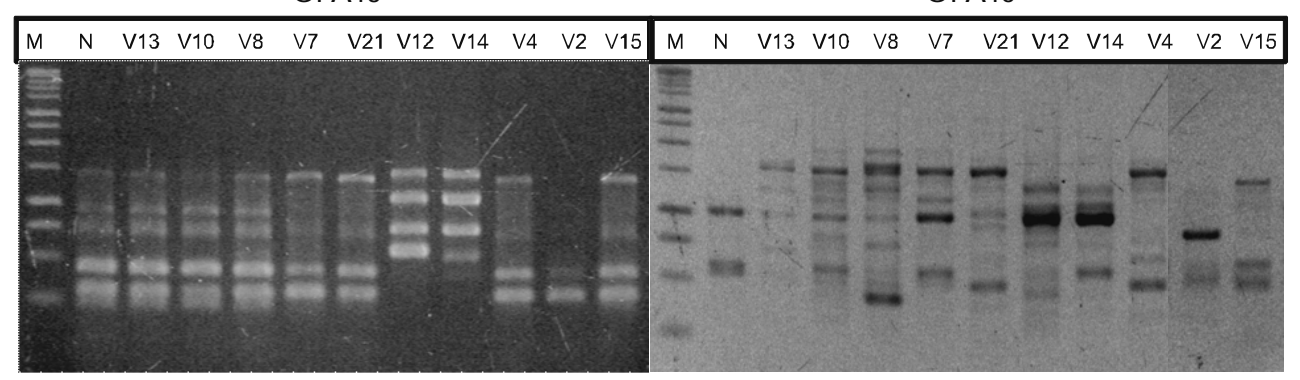

OPA18

OPA19

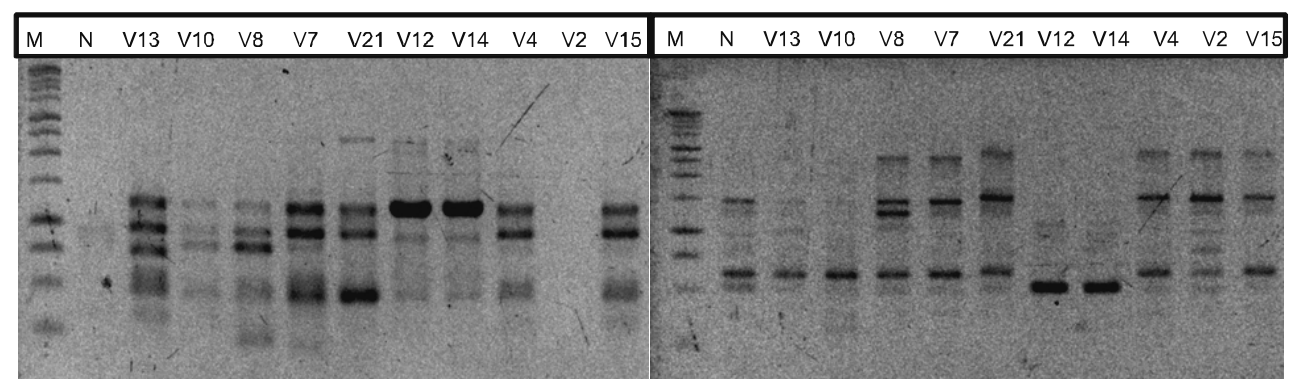

OPJ11

OPJ13

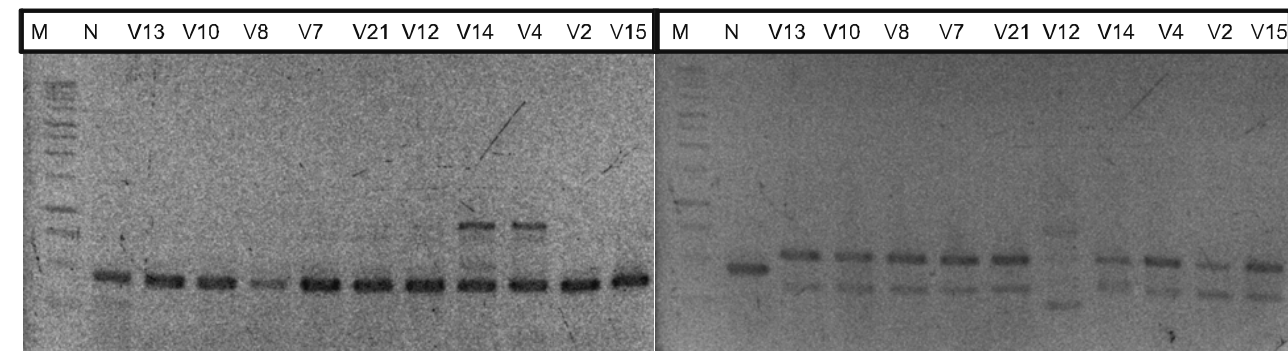

Figure 1 Profiles of DNA variants of pineapple cultures in population I (regenerated through shoot proliferation method), amplified by PCR using 10 RAPD markers. $\mathrm{M}=$ kb ladder; $\mathrm{N}=$ control plant from field; $\mathrm{V} 13$ = dwarf posture; $\mathrm{V} 10$ = albino stripe leaf; V8 = narrow leaf; V7 = spiness spot leaf; $\mathrm{V} 21$ = erect posture; V12 = wider leaf; V14 = powdery leaf; V4 = climb posture; V2 = needleleaf; and V15 = ultradwarf posture 


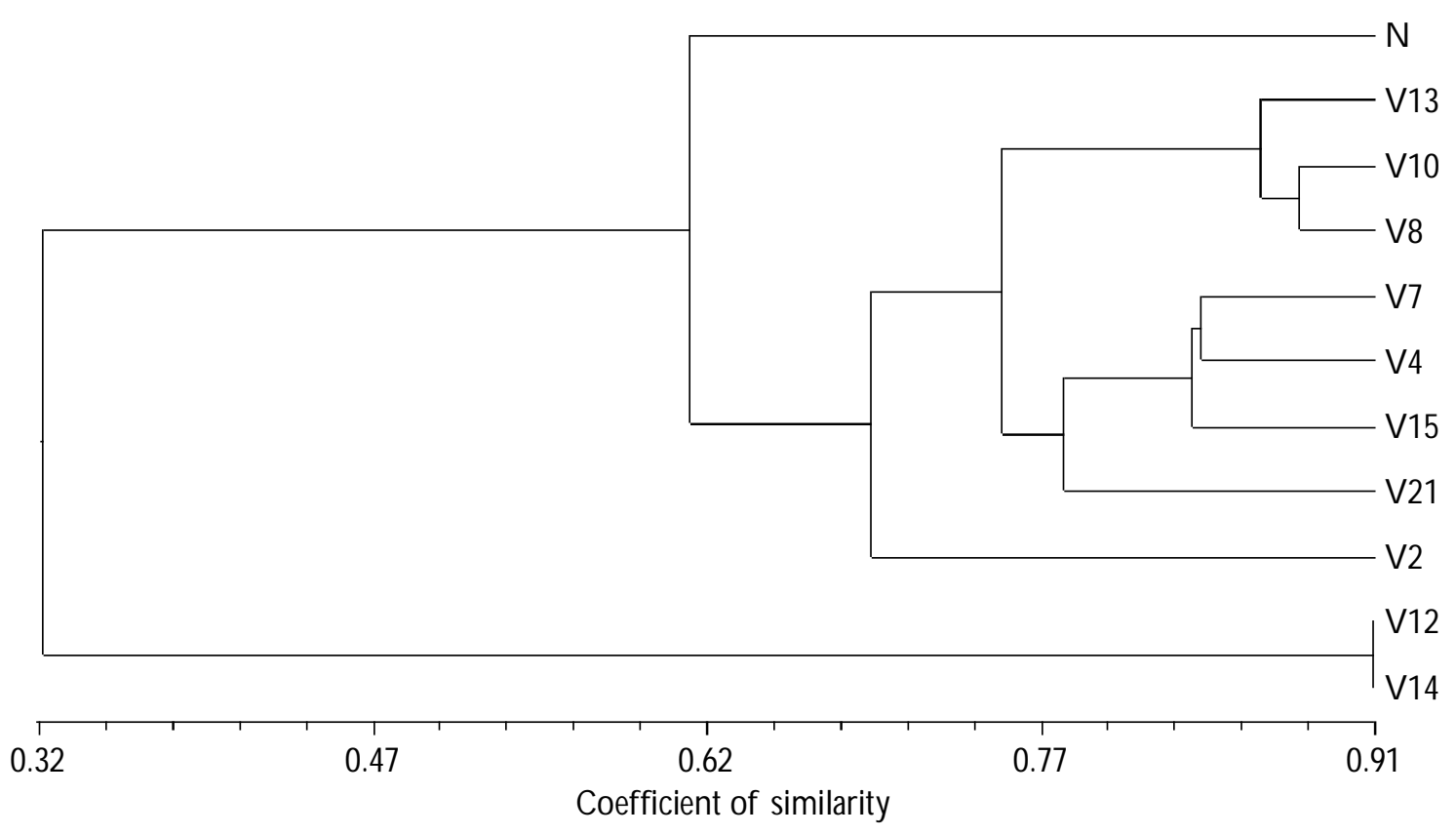

Figure2 Variability of variants derived from four year-old cultures of pineapple cultivar Smooth Cayenne regenerated through shoot proliferation method (Population I), performed by 10RAPD markers, based on (SAHN)-UPGMA analysis $(\mathrm{r}=0.97) . \mathrm{N}=$ control plant from field; $\mathrm{V} 13$ = dwarf posture; $\mathrm{V} 10$ = albino stripe leaf; $\mathrm{V} 8$ = narrow leaf; $\mathrm{V} 7$ = spiness spot leaf; $\mathrm{V} 21$ = erect posture; V12 = wider leaf; V14 = powdery leaf; V4 = climb posture; V2 = needle leaf; and V15 = ultradwarf posture
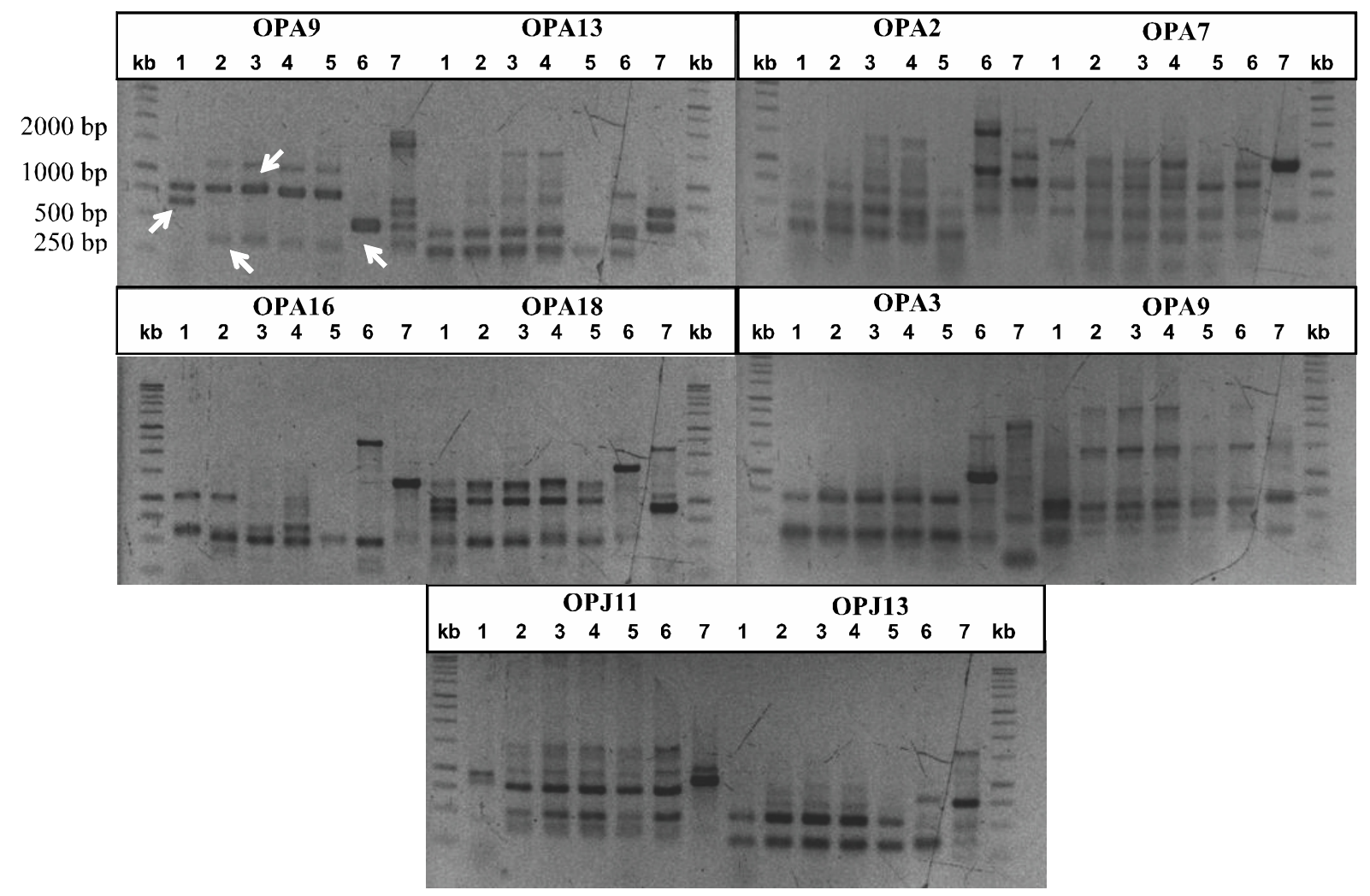

Figure 3 Profiles of DNA variants of pineapple cultures in population II, amplified by PCR using 10 RAPD markers. The arrows show polymorphic bands. $\mathrm{kb}=\mathrm{kb}$ ladder; $1=$ control plant; $2=$ cultures derived from direct organogenesis; 3 = cultures derived from indirect organogenesis induced by 2,4-D $21 \mu \mathrm{M} ; 4=$ cultures derived from indirect organogenesis induced by 2,4-D $41 \mu \mathrm{M} ; 5$ = cultures derived from indirect organogenesis induced by 2,4-D $62 \mu \mathrm{M} ; 6=$ cultures derived from somatic embryogenesis induced by 2,4-D; 7 = cultures derived from somatic embryogenesis induced by picloram 
Shorter Period of Culture Could Suppress the Somaclonal Variation of Pineapple

In order to further confirm our finding that culture period is the main contributor of genetic variation occurred in the in vitro culture of pineapple, the new population (Population III) was generated through shoot proliferation and direct organogenesis regeneration methods. The use of OPA primers was also better than OPJ. It can be concluded that OPA primers were more suitable for detecting pineapple off-type than OPJ primers. Interestingly, the new population revealed a higher level of similarity. The level of polymorphism in the Population III was lower than that in Population I (Fig. 5; Table 4). The NTSYS analysis yielded a dendrogram where similarity coefficient ranged from $0.65-1.0$. It separated the regenerants at the similarity coefficient of $0.65-0.85(r=0.96)$ to the control plant. It showed that the grouping is shifting to right, indicated the increase of similarity degree. It can be concluded that the use of the new population was better than the old population.

Table 3 The number of amplified product and polymorphic bands of population II, conducted by PCR method using 10 RAPD primers

\begin{tabular}{cccc}
\hline No & Primer & Number of amplified bands & Number of polymorphic bands \\
\hline 1 & OPA2 & 9 & 9 \\
2 & OPA3 & 9 & 9 \\
3 & OPA7 & 5 & 5 \\
4 & OPA9 & 8 & 8 \\
5 & OPA13 & 6 & 6 \\
6 & OPA16 & 5 & 5 \\
7 & OPA18 & 8 & 8 \\
8 & OPA19 & 5 & 3 \\
9 & OPJ11 & 5 & 4 \\
10 & OPJ13 & 5 & 3 \\
\hline & 65 & 60 \\
& Total number of bands & 100 & 92.3 \\
\hline
\end{tabular}

Note: Population II was derived from the normal phenotype-selected plantlets of four-year invitrocultures, regenerated through direct organogenesis, indirect organogenesis and somatic embryogenesis

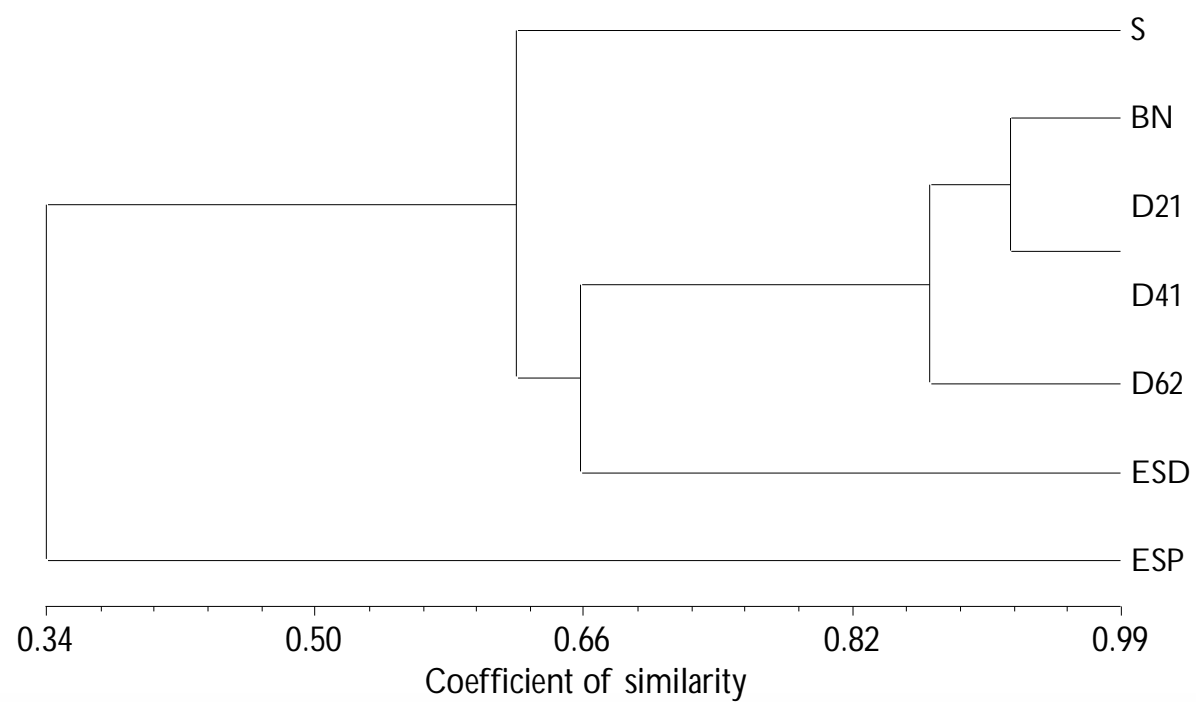

Figure 4 Variability of cultures of pineapple cultivar Smooth Cayenne in population II, performed by 10 RAPD markers, based on (SAHN)-UPGMA analysis $(\mathrm{r}=0.98)$. $\mathrm{N}=$ control plant; $\mathrm{BN}=$ cultures derived from direct organogenesis; D $21=$ cultures derived from indirect organogenesis induced by $21 \mu \mathrm{M} 2,4-\mathrm{D} ; \mathrm{D} 41=$ cultures derived from indirect organogenesis induced by $41 \mu \mathrm{M} 2,4-\mathrm{D} ; \mathrm{D} 62$ = cultures derived from indirect organogenesis induced by $62 \mu \mathrm{M} 2,4-\mathrm{D} ; \mathrm{ESD}=$ cultures derived from somatic embryogenesis induced by 2,4-D ; ESP = cultures derived from so matic embryogenesisinduced by picloram 
Table4 The number of amplified product and polymorphic bands of population III, conducted by PCR method using 10 RAPD primers

\begin{tabular}{cccc}
\hline No & Primer & Number of amplified bands & Number of polymorphic bands \\
\hline 1 & OPA2 & 4 & 4 \\
2 & OPA3 & 3 & 2 \\
3 & OPA7 & 5 & 2 \\
4 & OPA9 & 4 & 3 \\
5 & OPA13 & 5 & 1 \\
6 & OPA16 & 6 & 6 \\
7 & OPA18 & 6 & 3 \\
8 & OPA19 & 8 & 8 \\
9 & OPJ11 & 3 & 3 \\
10 & OPJ13 & 4 & 4 \\
\hline & Total number of bands & 48 & 36 \\
& Percentage (\%)
\end{tabular}

Note: Population III was derived from thenew invitrocultures, regenerated by shoot proliferation and direct organogenesis method

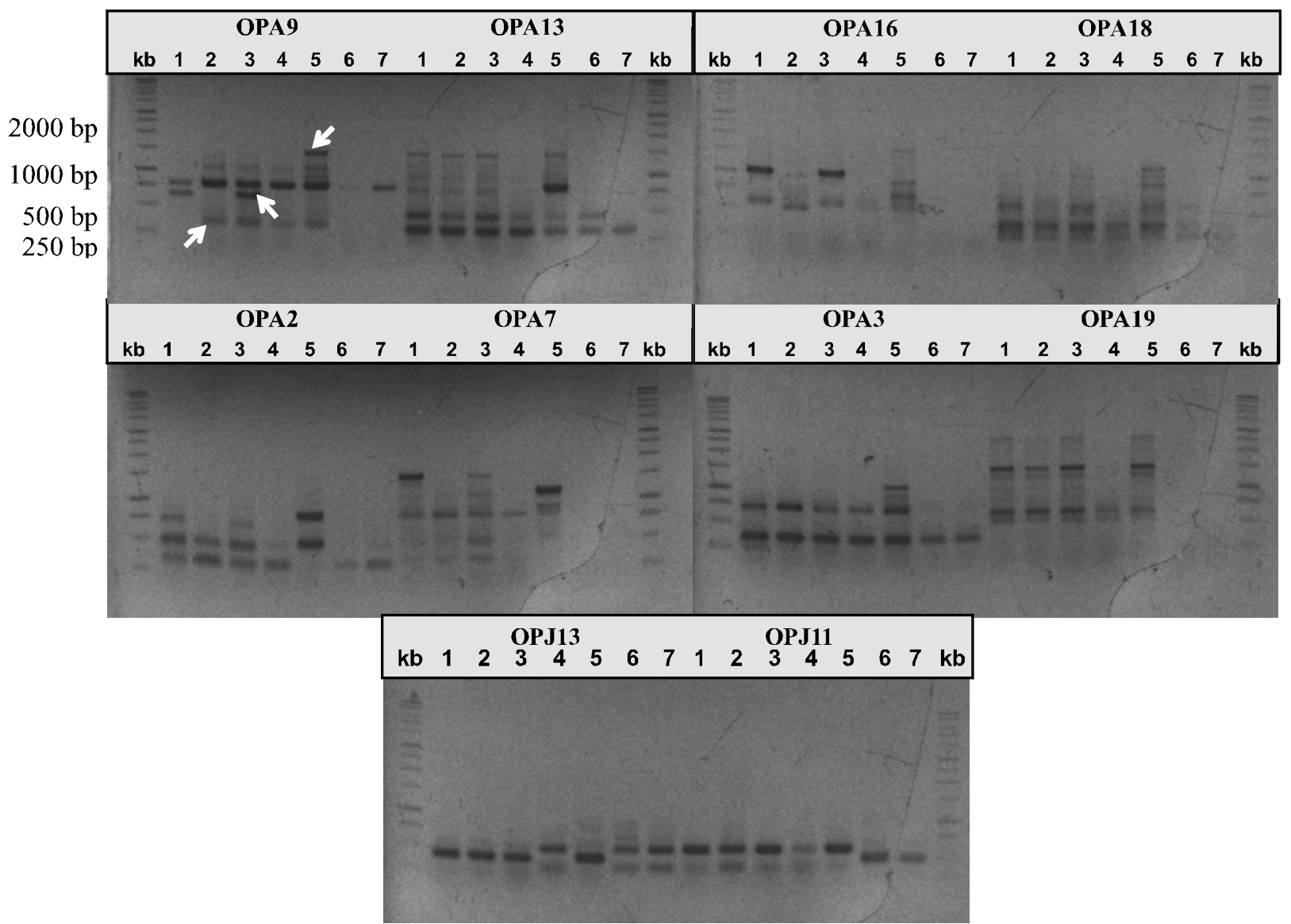

Figure 5 Profiles of variants D NA of pineapple cultures in population III, amplified by PCR using 10 RAPD markers. $\mathrm{kb}=$ $\mathrm{kb}$ ladder; (1) Clone Simadu from field; (2) Clone non-Simadu from field; (3) normal phenotype plant derived from shoot proliferation method; (4) cultures of Clone Simadu derived from shoot proliferation; (5) cultures of Clone non- Simadu derived from shoot proliferation; (6) cultures of Clone Simadu derived from direct organogenesis; and (7) cultures of Clonenon-Simadu derived from direct organogenesis. The arrows showed several polymorphic bands 


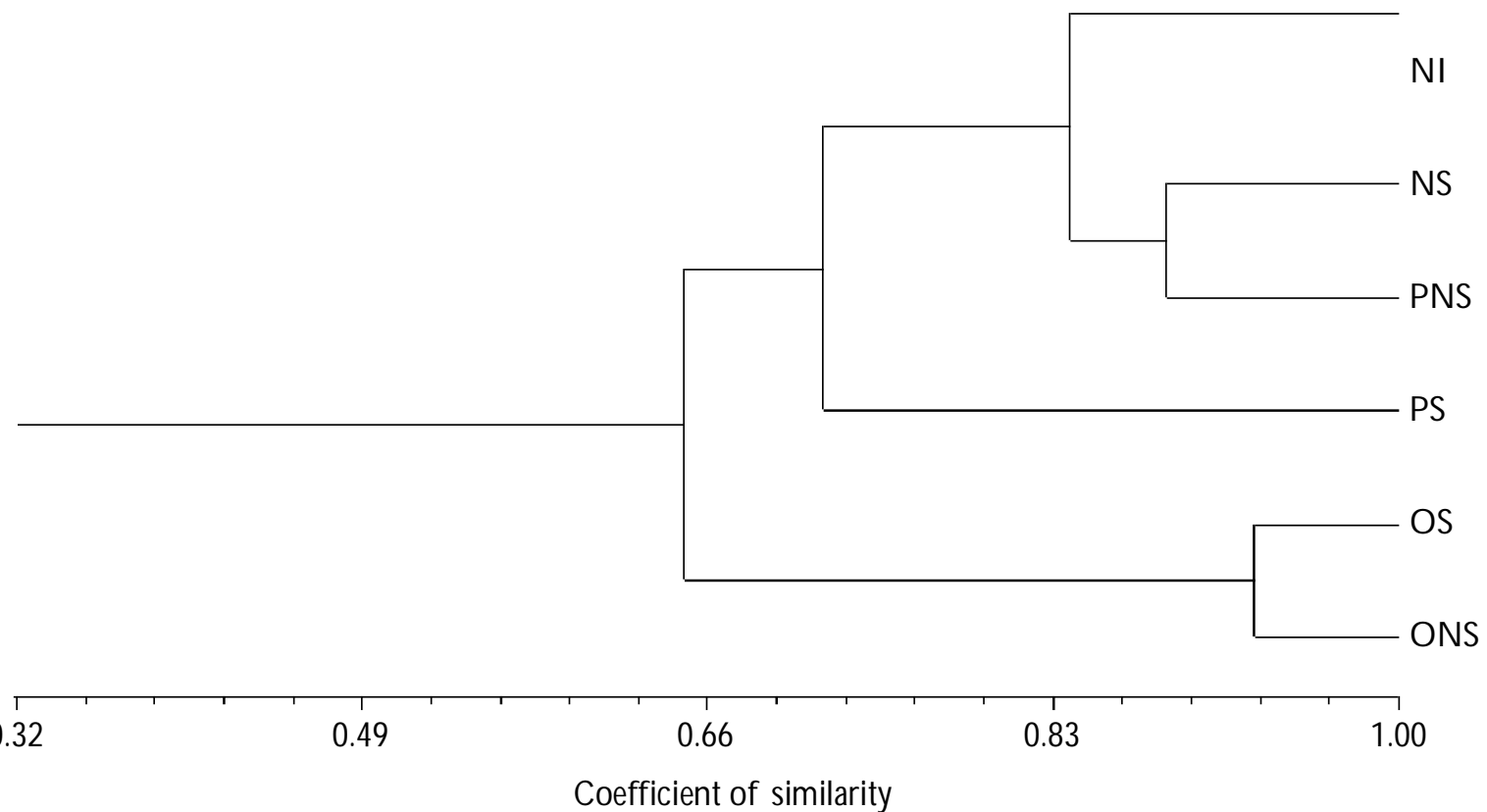

Figure6 Variability of cultures of pineapple cultivar Smooth Cayenne in the population III, performed by 10 RAPD markers, based on (SAHN)-UPG MA analysis ( $\mathrm{r}=0.96)$. $\mathrm{S}=$ Clone Simadu from field; NS = Clone non-Simadu from field; $\mathrm{NI}=$ normal phenotype plant derived from shoot proliferation method; $\mathrm{PS}$ = cultures of Clone Simadu derived from shoot proliferation; PNS = cultures of Clone non-Simadu derived from shoot proliferation; OS = cultures of Clone Simadu derived from direct organogenesis; and ONS = cultures of Clone non-Simadu derived from directorganogenesis

Monitoring the identity of cultures is important to establish the stability of a particular trait (Soneji $\epsilon a l$. 2002). O ur result showed that the molecular pattern of the normal phenotype plant derived from shoot proliferation method was identical with the control plant of Clone Simadu from field. Therefore, phenotypic screening in the individual cultures is considered to be applied as early detection of plant off-type during micropropagation. RAPD assay can also be applied as early detection of somaclonal variation in the population. According to Bairu eal. (2011), molecular technique enables detection of variants at the juvenile stage. Furthermore, getting rid of variants also could be performed in nurseries to avoid the occurrence of off-type in mass seedlings production (Mohamed 2007).

Generally, it can be concluded that the longperiod of cultures is the main contributor of somaclonal variation of pineapple, while the regeneration method and plant growth regulator could induce genetic variation. According to Leva đal. (2012), the system by which the regeneration is induced, type of tissue, explant source, media components and the duration of the culture cycle are some of the factors that are involved in inducing variation during invitroculture.

\section{CONCLUSIONS}

RAPD assay could detect genetic changes in micropropagated pineapple so that it can be used as early detection of off-type plant. The use OPA primers were better than OPJ primers. The longperiod of pineapple cultures was the main contributor of somaclonal variation. The use of direct organogenesis method was more recommended than the application of theindirect organogenesis and somatic embryogenesis since it does not undergo callus formation.

\section{ACKNOWLEDGEMENTS}

The authors acknowledged the financial support by Indonesia Agency for Agricultural Research and Development, Ministry of Agriculture of the Republic of Indonesia, through K K P3N program 2011. The authors also 
thanked Prof DrG.A. Wattimenaand Prof DrIka Mariska for their supervision and critical suggestions.

\section{REFERENCES}

Abdellatif KF, HegazyAE, Aboshama HM, Emara HA, ElShahed AA. 2012. Morphological and molecular characterization of somaclonal variations in tissue culture-derived banana plants. J Genet Eng Biotechnol 10:47-53.

Ahmed ABA, Rao AS, Rao MV, Taha M. 2011. Effect of picloram, additives and plant growth regulators on somatic embryogenesis of Phya nodiflora (L.) Greene. Braz Arch Biol Techn 63: 147-73.

Bairu MW, Fennell CW, Staden J van. 2006. The effect of plant growth regulators on somaclonal variation in Cavendish banana (Musa AAA cv. 'Zelig'). Sci Hort 108:347-51.

Bairu MW, Adeyemi O, Staden J van. 2011. Somaclonal variation in plants: causes and detection methods. PlantG rowth Regul 63:147-73.

Chen WH, Chen TM, Fu YM, Hsieh RM, Chen WS. 1998. Studies on somaclonal variation in Phalenopsis. PlantCell Rep 18:7-13.

Coppens d'Eeckenbrugge G, Leal F. 2003. Morphology, anatomy, and taxonomy. In: Bartholomew DP, Paull RE, Rohrbach KG, editors. The Pineapple Botany: Production and Uses. CABI Publishing.Wallingford. p13-32.

Eeuwens CJ, Lord SCR, D onough VR, Vallejo G, Nelson S. 2002. Effects of tissue culture conditions during embryoid multiplication on the incidence of "mantled" flowering in clonally propagated oil palm. PlantCell Tiss O rg Cult 70:311-23.

Feuser S, Meler K, Daquinta M, Guerra MP. 2003. Genotype fidelity of micropropagated pineapple (Anamas comosus) plantlets assessed by isozymes and RAPD markers. PlantCell Tiss O rg Cult 72: 221-27.

Firoozabady E, Moy Y. 2004. Regeneration of pineapplevia somatic embryogenesis and organogenesis. In vitro Cell D ev Biol_Plant 40:67-74.

International Board for Plant Genetic Resources. 1991. DesciptarsforPinæapde Rome.

Khoddamzadeh AA, Sinniah UR, Kadir MA, K adzimin SB, Mahmood M, Sreeramanan S. 2010. Detection of somaclonal variation by random amplified polymorphic D NA analysis during micropropagation of Phalaenopsis bellina (Rchb.f.) Christenson. AfrJ Biotechnol 9(40): 6632-9.

Koornneef M. 1991. Variation and mutant selection in plant cell and tissue culture. In: Jones $\mathrm{L}$, editor. Bidtehndogical Inmovationin CropImprovement London (UK): Butterworth-Heinemann Ltd. p 100-15.
Leva AR, Petruccelli R, Rinaldi LMR. 2012. Somaclonal variation in tissue culture: A case study with olive. In: Leva AR, editor. Reent Advances in Plant in vitro Culture Intech [Internet]. [cited 1 August 14]. Available from: http:/ / www.intechopen.com/ bo oks/ recent-advances-in-plant-in-vitroculture/ somaclonal variation.in-tissue-culture-a case-study-with-olive doi: 10.5772150367.

Masoud S, Hamta A. 2008. Cytogenetic analysis of somaclonal variation in regenerated plants of berseem clover (TnifdiumalexandhumL.). Cryologia 61(4):392-6.

Miguel C, Marum L. 2011. An epigenetic view of plant cells cultured in vitro: somaclonal variation and beyond. $\mathrm{J}$ Exp Bot62(11):3713-25.

Mohamed AE. 2007. Morphological and molecular characterization of some banana micro-propagated variants. IntJ Agri Biol 9(5): 707-14.

Murashige T, Skoog F. 1962. A revised medium for rapid growth and bioassays with tobacco tissue culture. Physiol Plant 15: 473-97.

Noormi R, Murugaiyah V, Subramaniam S. 2012. Optimization of callus induction medium for Hymenocallis littoralis (Melong kecil) using root and bulb explants.J Med Plants Res 6(12): 2309-16.

Nwauzoma AB, Jaja ET. 2013. A review of somaclonal variation in plantain (Musa spp): mechanisms and applications. J ApplBiosci 67: 5252-60.

Rani V, Raina SN. 2000. Genetic fidelity of organized meristem-derived micropropagated plants: A critical Reappraisal. In Vitro Cell Dev Biol Plant 36: 31930.

Roostika I, Mariska I, K humaida N, Wattimena GA. 2012a. Indirect organogenesis and somatic embryogenesis of pineapple induced by dichlorophenoxy acetic acid. J Agrobiogen 8(1): 8-18.

Roostika I, Mariska I, Khumaida N, Wattimena GA. 2012b. The effect of picloram and light on somatic embryogenesis regeneration of pineapple. IJAS 13(2): 43-53.

Roostika I. 2012c. Pemantapan metode organogenesis dan embriogenesis somatik nenas (Anamas comosus (L.) Merr.) serta deteksi dan reduksi keragaman somaklonal. Disatas. Bogor (ID ): Institut Pertanian Bogor.

Rout GR, Senapati SK, Aparajita S, Palai SK. 2009. Studies on genetic identification and genetic fidelity of cultivat ed banana using ISSR Markers. POJ 2(6): 250-8.

Santos MD M, Buso GCS, Torres AC. 2008. Evaluation of genetic variability in micropropagated propagules of ornamental pineapple (Anamas comous var. bracteatus (Lindley) Coppens and Leal) using RAPD markers. G en Mol Res 7(4): 1097-105.

Shahid MTH, Khan FA, Saeed A, Aslam M, Rasul F. 2014. D evelopment of somaclones in sugarcane genotype 
BF-162 and assessment of variability by random mplified polymorphic DNA (RAPD) and simple sequence repeats (SSR) markers in selected red rot resistant somaclones. Afr J Biotechnol 11(15): 350213.

Smith MK, Ko H-L, Hamill SD, Sanewski GM, G raham MW. 2003. Biotechnology. In: Bartholomew DP, Paull RE, Rohrbach KG, editors. The Pineapple Botany: Production and Uses. Wallingford (UK): CABI Publishing. P 57-68.

SonejiJR, Rao PS, Mhatre M. 2002. Suitability of RAPD for analyzing spined and spineless variant regenerants of pineapple (Anamas comoss L., Merr.). Plant Mol Biol Rep 20: 307a-I.

Soniya EV, Banerjee NS. Das MR. 2001. Genetic analysis of somaclonal variation among callus-denived plants of tomato. Curr Sci 80 (9): 1213-5.

Suminar E. 2010. Induksi keragaman genetik dengan mutagen sinar gamma pada nenas (Anamas comosus
(L.) Merr.) secara invitra Tesis Bogor (ID ): Institut Pertanian Bogor.

Tawar PN, Sawant RA, Dalvi SG, Nikam AA, Kawar PG, D eviarumath RM. 2008. An assessment of somaclonal variation in micropropagated plants of sugarcane by RAPD markers. SugarTech 10(2):1247.

Wakasa K. 1979. Variation in the plants differentiated from the tissue culture of pineapple. Japan J Breed 29(1): 13-22.

Williams JG, Kubelik AR, Livak KJ, RafalskiJA. 1990. D NA polymorphism amplified by arbitrary primers are useful as genetic markers. Nucleic Acids Res 18: 6531-5.

Zucchi MI, Arizono H, Morais VA, Fungaro MHP, Vieira MLC. 2002. G enetic instability of sugarcane plants derived from meristem cultures. G en Mol Biol 25(1): 91-6. 